Check for updates

Cite this: RSC Adv., 2018, 8, 24036

\title{
A scientometric study of the research on ion exchange membranes $\dagger$
}

\author{
Shanxue Jiang, (D) a Kimberly F. L. Hagesteijn, (D) ${ }^{a}$ Jin Ni (D) ${ }^{b}$ \\ and Bradley P. Ladewig (D) *a
}

A comprehensive scientometric approach was adopted to study the research on ion exchange membranes. The statistical analysis was conducted based on 21123 publications which were related to the topic of ion exchange membranes. Specifically, from 2001 to 2016, over 18000 articles were published on ion exchange membranes, indicating researchers' great interest in this topic. Especially, compared to 2001, the number of articles published in 2016 increased approximately six-fold. This trend continued in 2017 since over 2000 articles were published in the year of 2017. Also, these articles were spread across over 1000 different journals, near 100 countries/regions and over 5000 research institutes, revealing the importance of ion exchange membrane as well as the broad research interest in this field. Besides, the properties and applications of ion exchange membranes were also discussed statistically. Furthermore, keywords analysis indicated that fuel cell and proton exchange membrane had the highest cooccurrence frequency. Finally, research areas analysis revealed that ion exchange membranes had a close relation with chemistry, energy and materials.

Received 1st June 2018

Accepted 27th June 2018

DOI: $10.1039 / \mathrm{c} 8 \mathrm{ra0} 0486 \mathrm{~g}$

rsc.li/rsc-advances is named monovalent-ion-selective membranes, which, as indicated by its name, has the ability to separate monovalent ions from solutions and retain multivalent ions in solutions. ${ }^{18}$ For example, it can be used to remove arsenic and nitrate ions from groundwater, ${ }^{19}$ to concentrate reverse osmosis brines by electrodialysis, ${ }^{20}$ to generate energy through reverse electrodialysis, ${ }^{21}$ and so on. Besides, many different kinds of polymers have been investigated by researchers as potential ion exchange membranes via various synthesis methods. ${ }^{22-24}$ In a nutshell, the research in the field of ion exchange membranes is prosperous.

Meanwhile, in the age of big data, a lot of useful information can be obtained through data analysis. Therefore, instead of making decisions based solely on subjective experience, we can make decisions more scientifically with the help of data analysis. In other words, we can now conduct quantitative analysis as an insightful supplement to conventional qualitative analysis or review. As discussed above, a lot of work has been done on the topic of ion exchange membranes. Given researchers' great interest, it is necessary and important to give a timely update on this field so readers will not get lost in front of thousands of new papers published every year in this field. Although quite a few review papers have been published on the topic of ion exchange membranes, they are mainly based on the authors' subjective experience. There are very limited, if not zero, number of publications on the topic of ion exchange membranes using comprehensive statistical approach, or quantitative data analysis. Now the question is, how to carry out quantitative analysis on ion exchange membranes? Scientometrics is a quantitative
${ }^{a}$ Barrer Centre, Department of Chemical Engineering, Imperial College London, UK. E-mail: b.ladewig@imperial.ac.uk

${ }^{b}$ School of Chemical Engineering, College of Engineering and Physical Sciences, University of Birmingham, $U K$

$\dagger$ Electronic supplementary information (ESI) available. See DOI: $10.1039 / \mathrm{c} 8 \mathrm{ra} 04686 \mathrm{~g}$ 
Table 1 Examples of search terms for topic

\begin{tabular}{|c|c|c|}
\hline Search term & Separate term & Examples of separate term \\
\hline \multirow[t]{3}{*}{ “*Ion* exchange* membrane*” } & $*$ Ion* & Ion, cation, anion, ionic, cationic, anionic \\
\hline & Exchange* & $\begin{array}{l}\text { Exchange, exchanger, exchangeable, } \\
\text { exchanged }\end{array}$ \\
\hline & Membrane* & Membrane, membranes \\
\hline \multirow[t]{2}{*}{ “*Bipolar membrane*” } & *Bipolar & Bipolar, ambipolar \\
\hline & Membrane* & Membrane, membranes \\
\hline & Membrane* & Membrane, membranes \\
\hline \multirow{3}{*}{ “*Polymer* electrolyte* membrane*" } & *Polymer* & Polymer, copolymer, polymeric \\
\hline & Electrolyte* & Electrolyte, electrolytes \\
\hline & Membrane* & Membrane, membranes \\
\hline “*Ion* *selective membrane*” & $*$ Ion* & Ion, cation, anion, ionic, cationic, anionic \\
\hline \multirow[t]{3}{*}{ "Proton* conduct* membrane*" } & Proton* & Proton, protonic \\
\hline & Conduct* & Conducting, conductive \\
\hline & Membrane* & Membrane, membranes \\
\hline \multirow{3}{*}{ “*Ion* exchange* film*" } & *Ion* & Ion, cation, anion, ionic, cationic, anionic \\
\hline & Exchange* & $\begin{array}{l}\text { Exchange, exchanger, exchangeable, } \\
\text { exchanged }\end{array}$ \\
\hline & Film* & Film, films \\
\hline
\end{tabular}

study of the progress of science and scientific research, ${ }^{25}$ and is being widely used by researchers in various fields, such as sustainability, ${ }^{26}$ building information modelling, ${ }^{27}$ antibiotics, ${ }^{28}$ and so on. This paper aims to provide a comprehensive statistical study on the topic of ion exchange membranes through scientometric approach.

\section{Materials and methods}

The data used in this study was obtained from the database of Web of Science Core Collection with time span of 2001-2016, with citation index of Science Citation Index Expanded (SCIEXPANDED) and with the following search terms for topic:

("*ion* exchange* membrane*" or "*bipolar membrane*" or "proton* exchange* membrane*" or "*polymer* electrolyte* membrane*" or "*ion* *selective membrane*" or "*ion* conduct* membrane*" or "proton* conduct* membrane*" or "*ion* exchange* film*")

Examples of search terms were listed in Table 1. For example, "*ion* exchange* membrane*" included terms like "ion exchange membrane", "ion exchange membranes", "cation exchange membrane", "anionic exchange membrane", and so on. A total of 21123 publications met this search criteria. Full record of these publications was downloaded as .txt files and analyzed by software programs including Microsoft Excel, SPSS, ATLAS.ti, BibExcel, and Gephi. As an alternative, python programming skills can be helpful to process the results. The parts of full record data studied included title, address, publication name, language, document type, keywords, abstract, citations, yeas published, and research areas. Raw data was provided in Data repository and detailed data processing procedures were provided in ESI. $\dagger$

\section{Results and discussion}

\subsection{Document types}

The publications were divided into 10 document types, where article was the dominating type accounting for $86.0 \%$ of the total. As shown in Fig. 1, the next two types were proceedings paper and review, which had a percentage of $8.0 \%$ and $3.7 \%$,

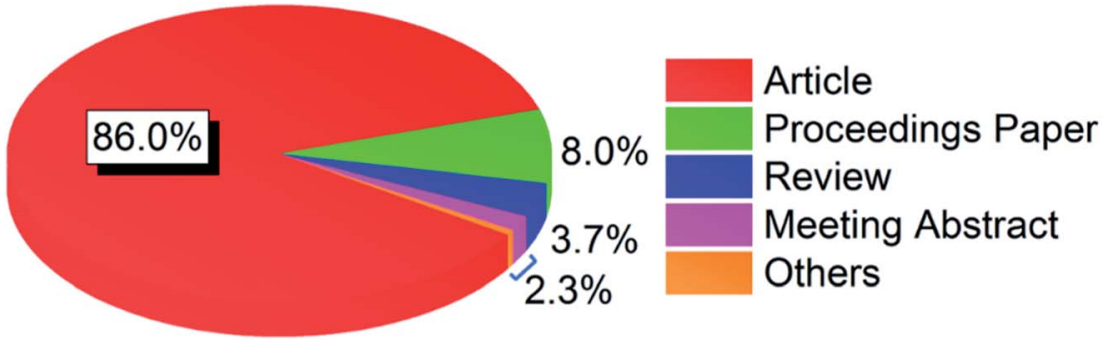

Fig. 1 Percentage distribution of document types. 


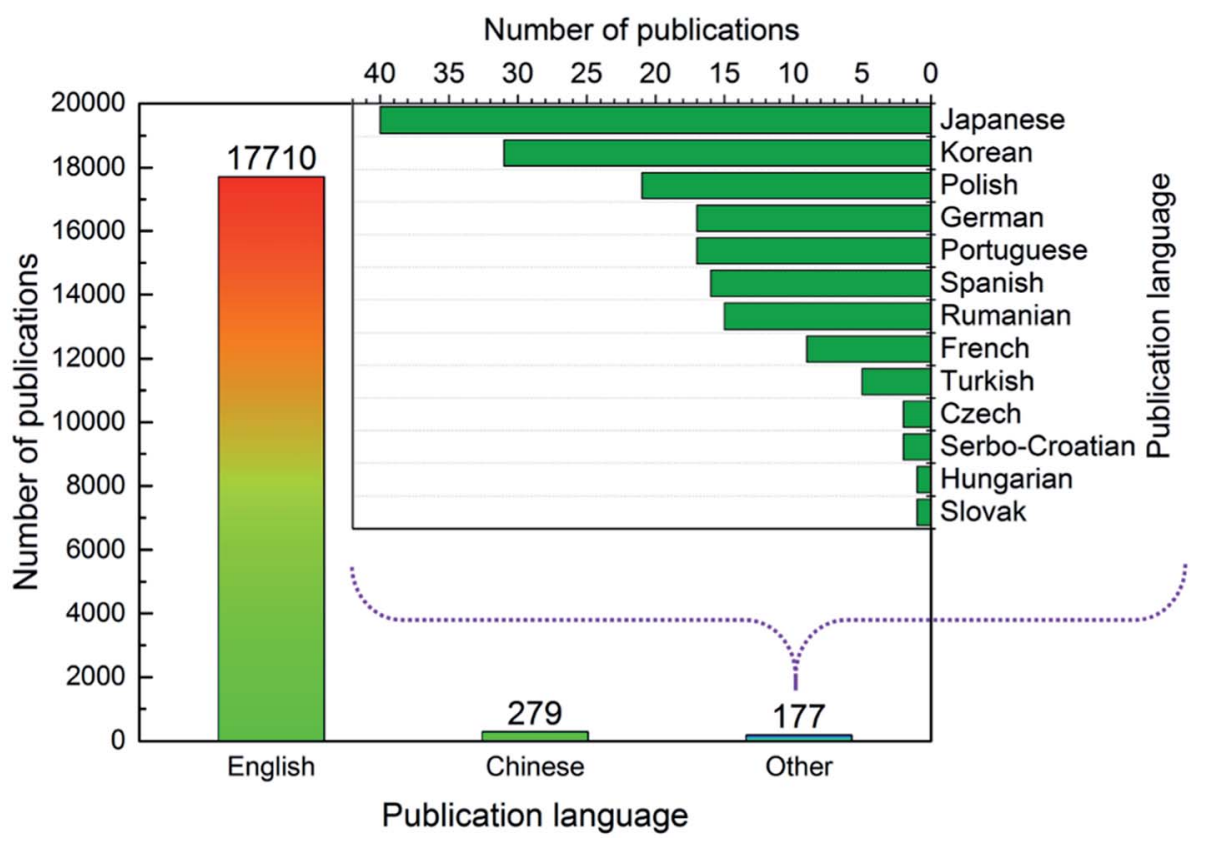

Fig. 2 Number of publications in different languages.

respectively. The fourth document type was meeting abstract, which accounted for $1.7 \%$ of the total. The remaining six document types with a total percentage of $0.6 \%$ were correction, book chapter, editorial material, letter, news item, and retracted publication, respectively. The following analysis was based on articles only since it was the main document type with a total number of 18166 .

\subsection{Publishing languages}

As shown in Fig. 2, most articles were published in English (97.5\%), followed by Chinese (1.5\%). Articles published in other languages (e.g., Japanese, Korean) made up only $1.0 \%$ of the total articles. Given that the most common publishing journals for ion exchange membrane research were English-language journals (see 3.4), it was expected that English was the most common publication language.

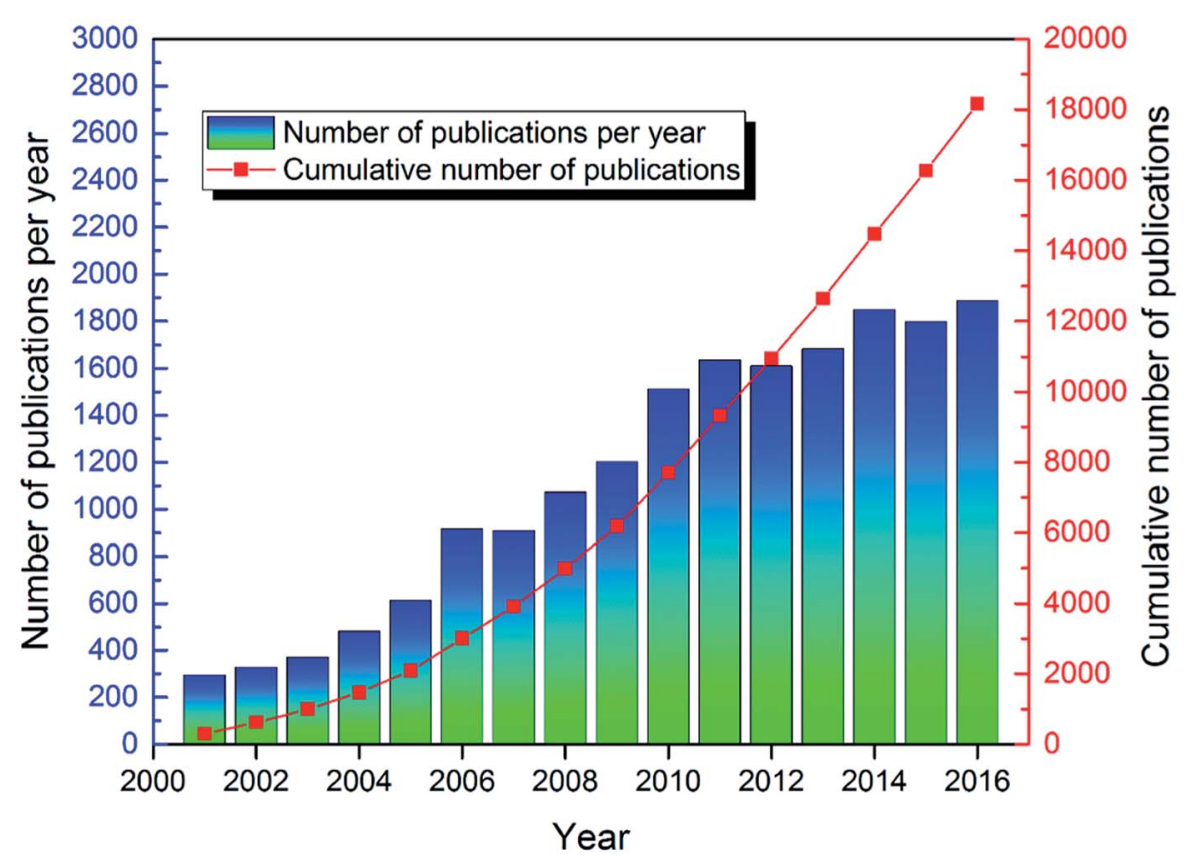

Fig. 3 Number of publications per year and cumulative number of publications on ion exchange membranes since 2001. 
Table 2 Top 20 most publishing journals ${ }^{a}$

\begin{tabular}{lll}
\hline ID No. & Journal name & Publisher \\
\hline 1 & Journal of Power Sources & Elsevier \\
2 & International Journal of Hydrogen Energy & Elsevier \\
3 & Journal of Membevier & ECS \\
4 & Journal of the Electrochemical Society & Elsevier \\
5 & Electrochimica Acta & John Wiley \& Sons \\
6 & Journal of Applied Polymer Science & RSC \\
7 & RSC Advances & John Wiley \& Sons \\
8 & Fuel Cells & Elsevier \\
9 & Desalination & ASME \\
10 & Journal of Fuel Cell Science and Technology & ACS \\
11 & Macromolecules & Elsevier \\
12 & Polymer & RSC \\
13 & Journal of Materials Chemistry A & ACS \\
14 & Journal of Physical Chemistry C & ACS \\
15 & Journal of Physical Chemistry B & Elsevier \\
16 & Electrochemistry Communications & Elsevier \\
18 & Solid State Ionics & Elsevier \\
19 & Separation and Purification Technology & ACS \\
20 & ACS Applied Materials \& Interfaces & RSC
\end{tabular}

${ }^{a}$ ECS refers to Electrochemical Society; RSC refers to Royal Society of Chemistry; ASME refers to American Society of Mechanical Engineers; ACS refers to American Chemical Society.

\subsection{Publishing trend}

As shown in Fig. 3, from 2001 to 2016, over 18000 articles were published on the topic of ion exchange membranes, indicating researchers' great interest in this topic. Specifically, compared to 2001 , the number of articles published in 2016 increased approximately six-fold. From 2001 to 2011 there was a rapid increase in the annual number of articles published on this topic. Then, the speed slowed down. From 2011 to 2013, and from 2014 to 2016, the increase in number of annual publications seemed to reach a plateau around 1600 and 1800, respectively. This might suggest that the early 2000 s was a period of rapidly evolving research on ion exchange membranes that stabilized somewhat recently. Despite this, the topic of ion exchange membranes is still an active research topic given that since 2011, over 1600 articles were published annually. This trend continued in 2017 since over 2000 articles were published in the year of 2017. Actually, in recent years, there were some quite exciting and new studies in the field of ion exchange membranes, which were discussed in detail in the following sections.

\subsection{Publishing journals}

The 18166 articles in this study were spread across 1092 different journals, which indicated the popularity and diversity

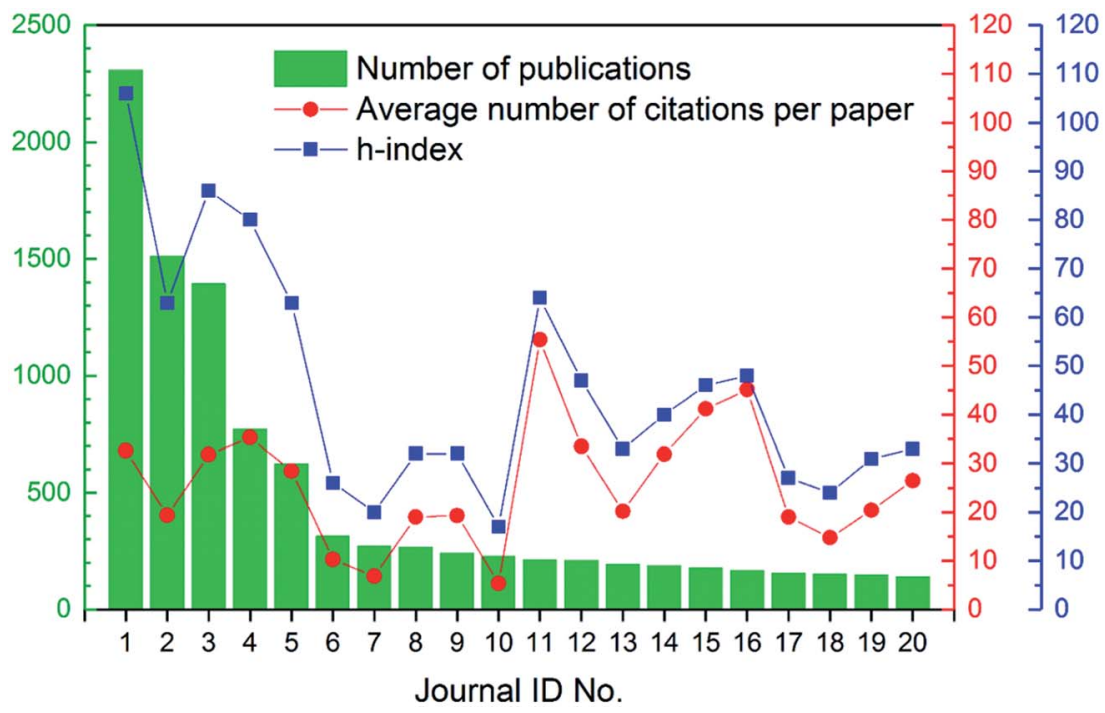

Fig. 4 Number of publications, average number of citations per paper, and h-index of the top 20 most publishing journals. 


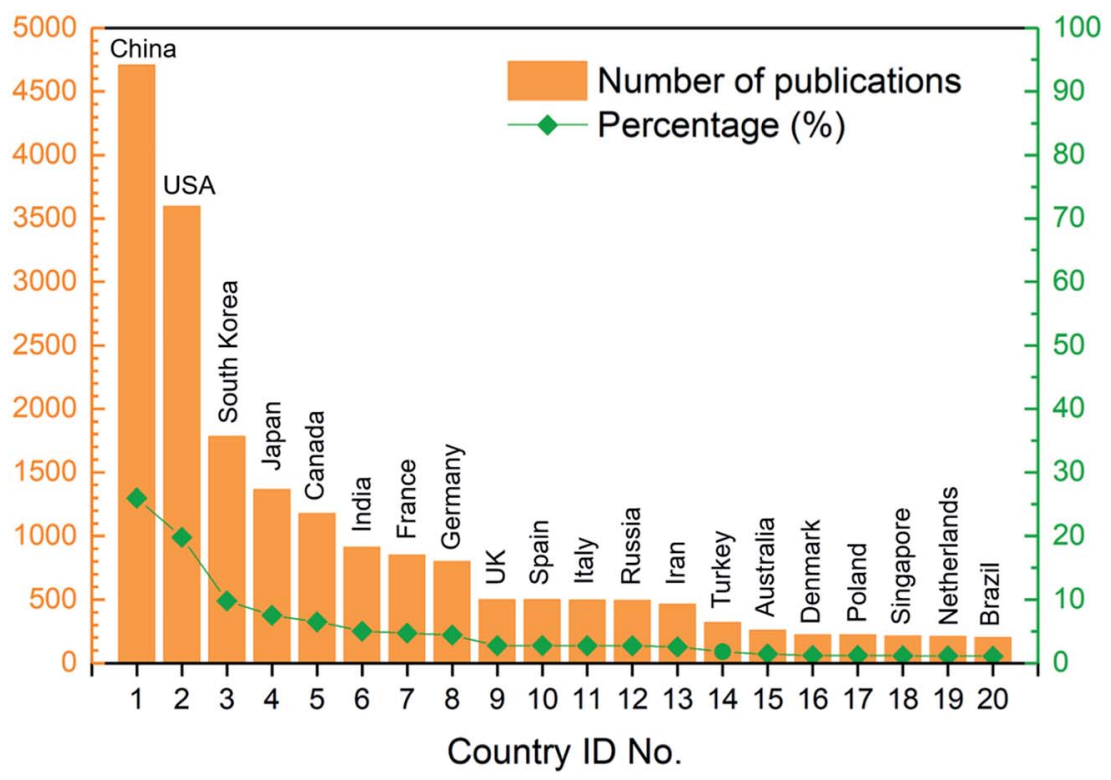

Fig. 5 Number of publications and corresponding percentage of the top 20 most publishing countries.

of this research field. On the other hand, $80.0 \%$ of the journals had eight or fewer articles published on the topic of ion exchange membranes (see Fig. S1 in ESI $\dagger$ ). The top twenty most publishing journals were summarized in Table 2. Interestingly, these twenty journals accounted for $53.3 \%$ of all articles published in the 16 year time span. Besides, as revealed by Table 2, Elsevier, American Chemical Society (ACS), and Royal Society of Chemistry (RSC) were the top three most common publishers. As shown by Fig. 4, in general, h-index was higher than average number of citations per paper. But the really interesting thing was that Fig. 4 revealed a positive correlation between h-index

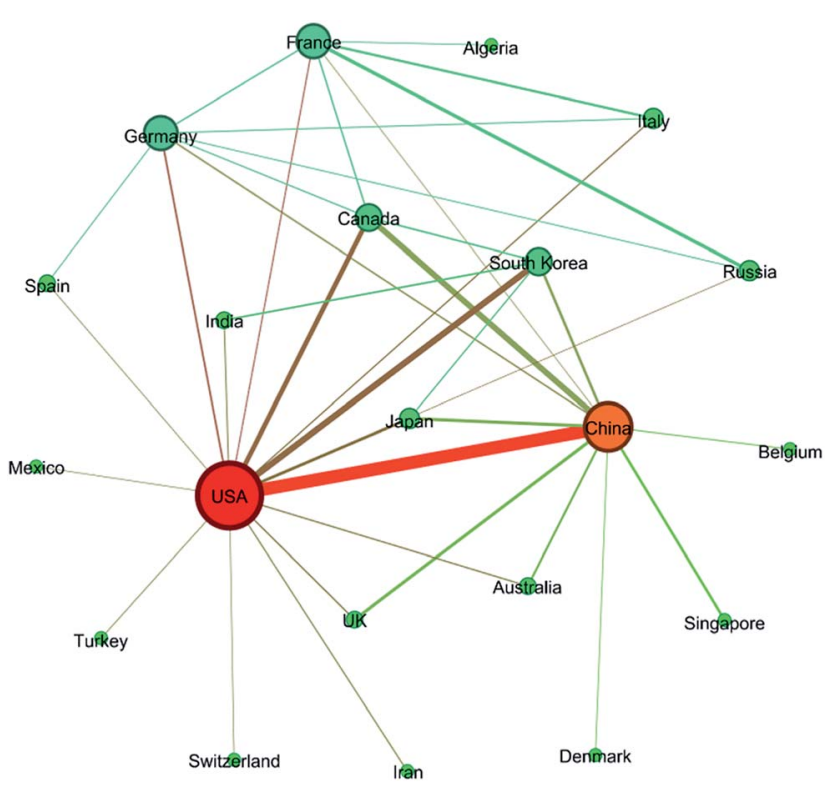

Fig. 6 Network graph showing collaborations between countries Countries with collaborations of more than 20 times were connected with lines. and citations, which was comprehensible as h-index was a composite of the number of papers and citations (namely impact). To sum up, as revealed by the journals analysis, the field of ion exchange membranes was quite popular and diversified, but it did have its own focused-areas. In fact, as discussed below, ion exchange membranes had many important applications, with water and energy being the two most concerned ones.

\subsection{Publishing countries/regions}

In general, 98 countries/regions in total had contributions to these articles, which revealed that the field of ion exchange membranes was of global interest. Among these countries/ regions, 40 countries/regions published more than 40 articles and 30 countries/regions published more than 100 articles during the 16 year period (see Table S2 in ESI†े). As revealed by

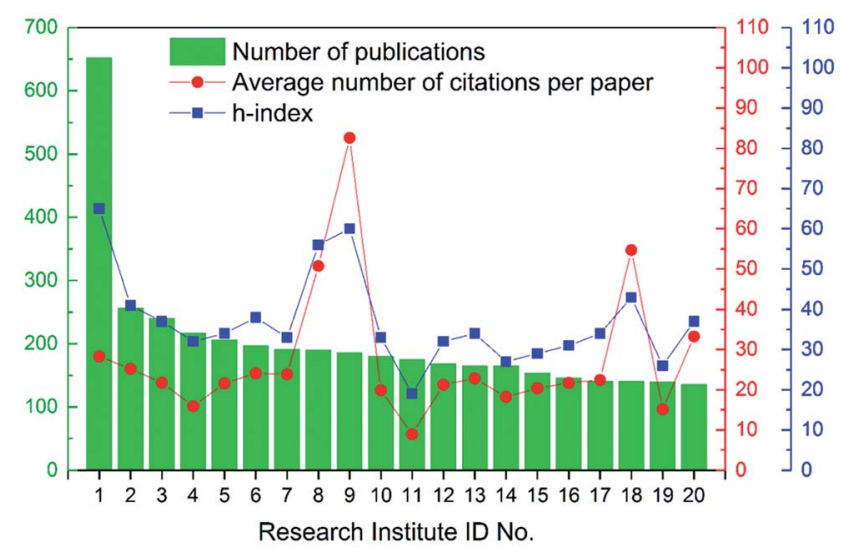

Fig. 7 Number of publications, average number of citations per paper, and $\mathrm{h}$-index of the top 20 most publishing research institutes. 
Table 3 Top 20 most publishing research institutes

\begin{tabular}{ll}
\hline ID No. & Research Institute \\
\hline 1 & Chinese Academy of Sciences \\
2 & University of Science and Technology of China \\
3 & Jilin University \\
4 & Shanghai Jiao Tong University \\
5 & Seoul National University \\
6 & Tsinghua University \\
7 & Korea Institute of Science and Technology \\
8 & National Research Council Canada \\
9 & Pennsylvania State University \\
10 & Wuhan University of Technology \\
11 & Russian Academy of Sciences \\
12 & Indian Institutes of Technology \\
13 & Hanyang University \\
14 & Tianjin University \\
15 & Yuan Ze University \\
16 & Tokyo Institute of Technology \\
17 & Dalian University of Technology \\
18 & University of South Carolina \\
19 & Kuban State University \\
20 & University of Connecticut
\end{tabular}

Fig. 5, China and USA were the top two most publishing countries. The following three countries whose article number exceeded 1000 were South Korea, Japan and Canada. On the other hand, $17.28 \%$ of the articles were published as a result of collaborations between two or more countries/regions. As shown in Fig. 6, around 40 pairs of countries published more than 20 articles together, where the USA/China pair had the most fruitful collaborations (also see Table S4 in ESI $\dagger$ ).

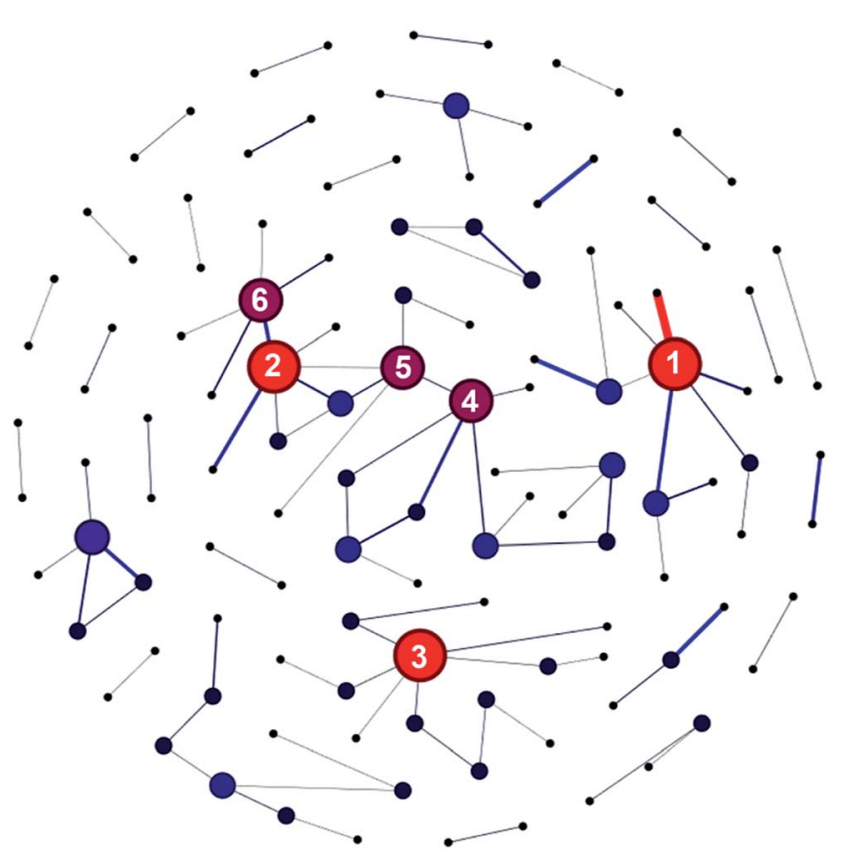

Fig. 8 Research institute collaboration network graph. Institutes whose collaborations exceeded 10 times were connected with lines. Note: (1) Chinese Academy of Sciences; (2) Korea Institute of Science and Technology; (3) National Taiwan University; (4) National Research Council Canada; (5) Hanyang University; (6) Seoul National University.
Table 4 Top 20 most-cited articles ${ }^{a}$

\begin{tabular}{|c|c|c|c|c|}
\hline No. & Articles & $\mathrm{TC}$ & PY & Research category \\
\hline 1 & V. R. Stamenkovic ${ }^{29}$ & 2096 & 2007 & PEMFC \\
\hline 2 & B. Lim et $a ._{.}^{30}$ & 1811 & 2009 & PEMFC \\
\hline 3 & M. Lefèvre et al. ${ }^{31}$ & 1512 & 2009 & PEMFC \\
\hline 4 & J. Greeley et al. ${ }^{32}$ & 1118 & 2009 & PEMFC \\
\hline 5 & G. Nagel et al. ${ }^{33}$ & 1083 & 2003 & CSM \\
\hline 6 & H. Liu et $a l^{34}$ & 1017 & 2004 & MFC \\
\hline 7 & F. Wang et $a l^{35}$ & 868 & 2002 & PEMFC \\
\hline 8 & E. J. Popczun et al. ${ }^{36}$ & 859 & 2013 & HER \\
\hline 9 & D. B. Levin et al. ${ }^{37}$ & 816 & 2004 & PEMFC \\
\hline 10 & P. J. Ferreira et al. ${ }^{38}$ & 781 & 2005 & PEMFC \\
\hline 11 & K. Schmidt-Rohr et al. ${ }^{39}$ & 706 & 2008 & PEMFC \\
\hline 12 & C. G. Van de Walle et al. ${ }^{40}$ & 666 & 2003 & $\mathrm{PEMFC}^{b}$ \\
\hline 13 & J. H. Nam et al. ${ }^{41}$ & 627 & 2003 & PEMFC \\
\hline 14 & C. Wang et al. ${ }^{42}$ & 625 & 2004 & PEMFC \\
\hline 15 & P. Xing et $a l^{43}$ & 622 & 2004 & PEMFC \\
\hline 16 & Z. H. Wang et al. ${ }^{44}$ & 609 & 2001 & PEMFC \\
\hline 17 & B. Logan et $a l^{45}$ & 603 & 2007 & MFC \\
\hline 18 & S. Cheng et al. $^{46}$ & 594 & 2006 & MFC \\
\hline 19 & S. M. Haile et $a l^{47}$ & 591 & 2001 & SAFC \\
\hline 20 & C. Rice et $a .^{48}$ & 537 & 2002 & DFAFC \\
\hline
\end{tabular}

${ }^{a}$ TC refers to total citations; PY refers to publishing year; PEMFC refers to proton exchange membrane fuel cell or polymer electrolyte membrane fuel cell; CSM refers to cation selective membrane; MFC refers to microbial fuel cell; SAFC refers to solid acid fuel cell; HER refers to hydrogen evolution reaction; DFAFC refers to direct formic acid fuel cell. ${ }^{b}$ The more direct research topic of this paper was hydrogen, understanding of which is important for PEMFC development.

\subsection{Publishing institutions}

In general, over 5000 research institutes had contributions to these articles, which again uncovered the broad research interest in the field of ion exchange membranes. Specifically, among these institutes, 34 institutes published 100 articles or more during the 16 year period (see Table S5 in ESI $\dagger$ ). As shown in Fig. 7 and Table 3, Chinese Academy of Sciences was the no. 1 most publishing research institute (over 650 articles), followed by University of Science and Technology of China. From another perspective, it should be pointed out that institutes like Chinese Academy of Sciences, Indian Institutes of Technology, and so on are centrally funded clusters of research institutes, which enabled their high production. In other words, the institutes listed in Table 3 can be roughly divided into two groups, namely independent universities such as Jilin University and "institute clusters" such as Chinese Academy of Sciences. Actually, there are quite a few research centres/groups in Chinese Academy of Sciences that focus on the field of ion exchange membranes as well as membrane applications, including but not limited to fuel cells, electrodialysis and electrolysis.

Besides, $48.13 \%$ of the articles were published as a result of collaborations between two or more research institutes. Furthermore, there were around 1000 pairs of research institutes that published two or more articles together. Chinese Academy of Sciences and University of Chinese Academy of Sciences had the most fruitful collaborations with each other (see Table S7 in ESI $\dagger$ ). As revealed by Fig. 8, Chinese Academy of 


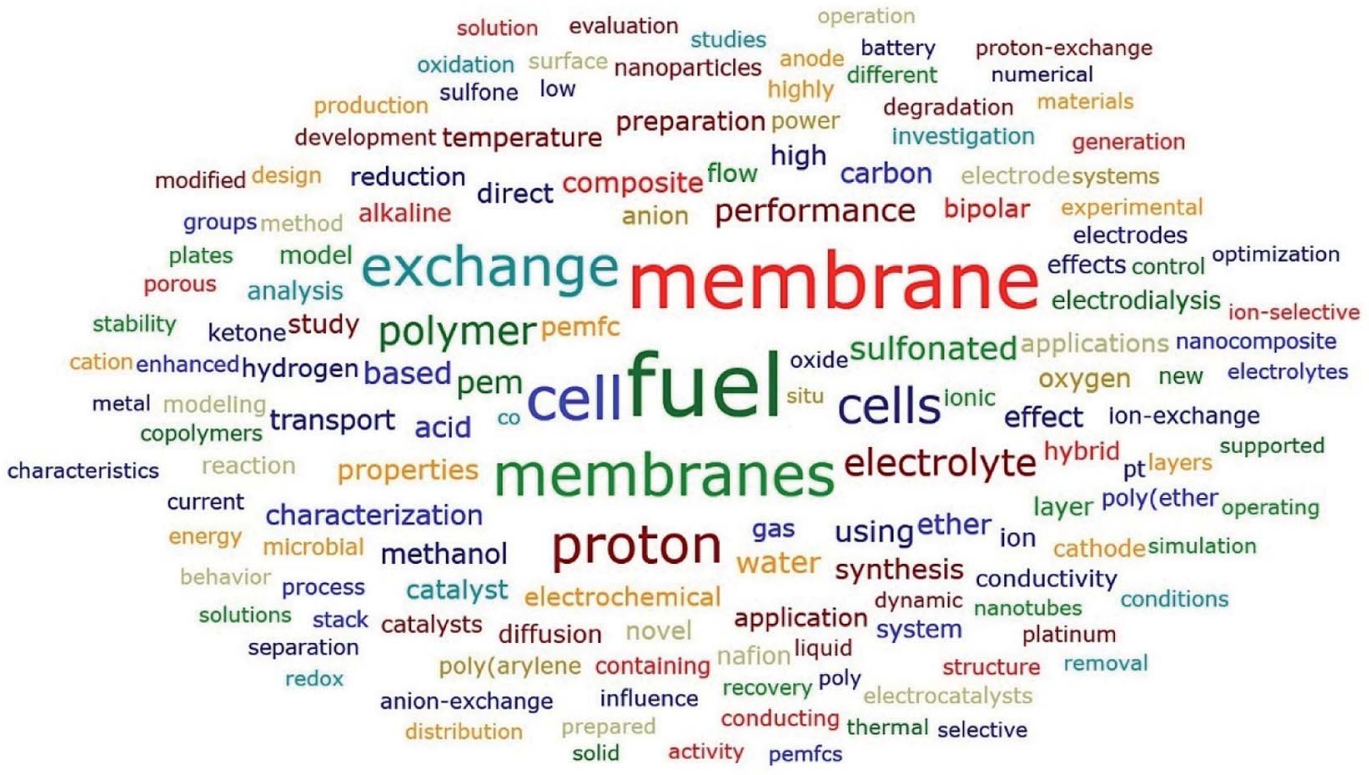

Fig. 9 Word cloud generated from titles with frequency no less than 200.

Sciences, Korea Institute of Science and Technology, and National Taiwan University ranked top three in terms of number of collaborating institutes. To be specific, take Chinese Academy of Sciences for example, it had collaborations with 6 different research institutes and published more than 10 articles together with each of these six institutes.

\subsection{Most-cited papers}

The top twenty most-cited articles on the topic of ion exchange membranes since 2010 were summarized in Table 4, including total citations, year published as well as research direction. It should be pointed out that the research directions were not necessarily mutually exclusive. For example, direct formic acid fuel cell (DFAFC) was a subcategory of proton exchange membrane fuel cell or polymer electrolyte membrane fuel cell (PEMFC). Among the articles listed in Table 4, it seemed that although ion exchange membranes had many applications, fuel cells were the most studied ones, which corresponded well with the following title and abstract analysis.

$$
\begin{aligned}
& \text { without porous } \\
& \text { significantly microscopy similar values applied } \\
& \text { exhibited present electrodes pressure degradation temperatures } \\
& \begin{array}{c}
\text { alkaline humidity well ions mechanical electron improved application } \\
\text { within layers direct }
\end{array} \\
& \text { hows material developed phase study airconcentration uptakeliquid (pemfc) } \\
& \text { area pem potential layer carbon prepared transport reaction time respectively } \\
& \text { increasing experimental voltage surface new propertiespaper pemfcdistribution } \\
& \text { significant ph stack thermal based higher cells performance low power electrochemical metal } \\
& \text { loading }{ }_{\text {operation }}^{\text {good }} \text { method polymer } \mathrm{Cell} \text { membranes }{ }_{\text {density }}^{\text {can stability reduction applications }} \\
& \text { density oxygenstudied } \text { transfer } \\
& \text { effects conditions results } \\
& \text { test ratio electrodecatalyst } \\
& \text { formation chemical gas conductivity fuel highion exchange different efficiency novel (pem) } \\
& \text { however groups solution used one } \\
& \text { parameters energy electrolyte using water proton nafion ionic range } \\
& { }^{\text {use }} \text { mass compared system pt degrees temperature flow process capacity size } \\
& \text { various analysis }{ }_{c o} \text { methanol hybrid } \\
& \text { containing content cathodecomposite anode showbipolar channel } \\
& \text { spectroscopy sulfonated activity effect } \text { structure order single }^{\text {relative }} \\
& \text { proposed permeability resistance maximum measured } \\
& \text { measurements addition }{ }_{\mathrm{x} \text {-ray }} \text { data design electrical }
\end{aligned}
$$

Fig. 10 Word cloud generated from abstracts with frequency no less than 1000. 
Table 5 Common applications of ion exchange membranes ${ }^{a}$

\begin{tabular}{ll}
\hline Application & Number of abstracts \\
\hline Fuel cell & 10261 \\
Electrodialysis & 843 \\
Electrolysis & 447 \\
Desalination & 256 \\
Redox flow battery & 225 \\
Bipolar membrane electrodialysis & 182 \\
Diffusion dialysis/Donnan dialysis & 157 \\
Water treatment & 104 \\
Reverse lectrodialysis & 82 \\
Capacitive deionization & 52 \\
Electrodeionization & 43 \\
Water purification & 31 \\
Electro-electrodialysis & 25 \\
a The applications listed in this table were not necessarily mutually \\
exclusive.
\end{tabular}

\subsection{Title analysis}

As shown in Fig. 9, fuel was the most common word in titles, which had a frequency of 7515 , meaning that over $40 \%$ of the articles contained the word "fuel" in their titles. Following fuel were membrane, cell and membranes, which ranked $2^{\text {nd }}, 3^{\text {rd }}$, and $4^{\text {th }}$, respectively. There was no surprise that the two words "membrane" and "membranes" had top rankings in terms of frequency. A further analysis revealed that 7350 articles out of the 18166 articles contained fuel cell or fuel cells, which indicated that fuel cell(s) was the most frequently studied subfield in the field of ion exchange membranes. The following two were exchange and proton. Similarly, a further analysis showed that 2901 articles contained proton exchange membrane or proton exchange membranes, which indicated that proton exchange membrane(s) was the most frequently studied membrane type of ion exchange membranes. Polymer and electrolyte were another two common words appearing in the titles. A further

Table 6 Common properties of ion exchange membranes ${ }^{a}$

\begin{tabular}{ll}
\hline Property & Number of abstracts \\
\hline Conductivity & 4952 \\
Stability & 3301 \\
Water uptake & 2175 \\
Resistance & 2158 \\
Ion exchange capacity & 1600 \\
Permeability & 1465 \\
Morphology & 1150 \\
Thermal stability & 1145 \\
Swelling & 1033 \\
Hydrophilic & 979 \\
Hydrophobic & 874 \\
Mechanical & 833 \\
properties & \\
Chemical properties & 519 \\
Chemical stability & 466 \\
Oxidative stability & 337 \\
Dimensional stability & 306 \\
a The properties listed in this table were not & necessarily mutually \\
exclusive. &
\end{tabular}

analysis revealed that polymer electrolyte membrane(s) was contained in the titles of 1404 articles. In fact, polymer electrolyte membrane fuel cells (PEMFCs) was often used as a whole. Furthermore, 141 titles contained cation exchange membrane(s) while 517 titles contained anion exchange membrane(s). However, this did not necessarily mean that cation exchange membranes were less popular compared to anion exchange membranes. Another noteworthy highfrequency word was "sulfonated", which was contained in the titles of 1624 articles out of the 18166 articles. Given the high frequency of proton exchange membrane(s) which was a kind of cation exchange membranes, it was understandable that sulfonate also had a high frequency as well, since sulfonate group was the most common functional group for cation exchange membranes. On the other hand, it indicated that a lot of studies on sulfonated polymers had been done, which was further verified by the fact that 1252 articles contained "sulfonated poly", among which sulfonated poly(ether ether ketone) (SPEEK) was the most studied one (Nafion was excluded from this comparison and was analyzed specifically below).

\subsection{Abstract analysis}

Fig. 10 showed similar frequency distributions as Fig. 9. The word "water" appeared more frequently in the abstracts than in the titles. To be specific, "water" was the fifth most common word in abstracts, which appeared in 6689 abstracts, revealing the important relationship between water and ion exchange membranes. As shown in Table 5, fuel cell was the most common application of ion exchange membranes, followed by electrodialysis. As revealed by Fig. 10 and Table 6, conductivity was the most studied membrane property, indicating its important position in ion exchange membranes. Besides, stability was another most studied membrane property. In order to make membranes commercially feasible and more competitive, it is crucial that excellent membrane stability is guaranteed. Furthermore, the word "Nafion" appeared 3143 times in these abstracts, meaning that $17.40 \%$ of the abstracts contained "Nafion", which indicated its important role in the field of ion exchange membranes. Nafion is a sulfonated tetrafluoroethylene based perfluorinated polymer ${ }^{49}$ which is widely used in many applications such as fuel cells. ${ }^{50}$ Other common studied polymers included poly(ether ether ketone) (PEEK), polybenzimidazole (PBI), and so on (see Table S8 in ESI $\dagger$ for more details).

From another perspective, the above analysis is mainly focused on the statistical aspect of ion exchange membranes. In other words, it is powerful in revealing the "major trend" or "broad interest" of this field but is less powerful to reveal the latest research breakthroughs or issues. Therefore, it is important to give a "human-knowledge-based" analysis on this topic, as a supplement. For example, bipolar membrane is gaining more research interest in recent years due to its high energyefficiency as well as environmental benefits. One special research interest is bipolar membrane water splitting. ${ }^{51}$ In addition to conventional preparation methods (e.g., casting technique), researchers are also exploring other novel 
Table 7 Top 20 most used keywords for ion exchange membranes

\begin{tabular}{|c|c|c|c|}
\hline Keyword & Number of articles & Percentage (\%) & Rank \\
\hline Fuel cell & 1386 & 9.86 & 1 \\
\hline PEMFC & 824 & 5.86 & 2 \\
\hline Proton exchange membrane fuel cell & 743 & 5.29 & 4 \\
\hline Fuel cells & 709 & 5.04 & 5 \\
\hline Proton conductivity & 699 & 4.97 & 6 \\
\hline Membranes & 369 & 2.63 & 9 \\
\hline Proton exchange membrane fuel cells & 346 & 2.46 & 10 \\
\hline Polymer electrolyte membrane & 326 & 2.32 & 11 \\
\hline Nafion & 325 & 2.31 & 12 \\
\hline Membrane & 323 & 2.30 & 13 \\
\hline Direct methanol fuel cell & 315 & 2.24 & 14 \\
\hline PEM fuel cells & 232 & 1.65 & 19 \\
\hline Durability & 222 & 1.58 & 20 \\
\hline
\end{tabular}

technologies, such as electrospinning to control the layer thickness precisely. ${ }^{52}$ Another very promising topic is water electrolysis membranes. This technology is gaining growing interest due to its capacity to produce hydrogen from cheap and readily available resources, i.e., water. However, it does not mean the hydrogen production process is cheap. So one research interest is to reduce high capital cost as well as uncertainty related to this process. ${ }^{53}$ Besides, another interesting aspect of water electrolysis membranes is product gas crossover. $^{54}$ Finally, researchers are also developing new membranes, including mixed matrix membranes, ${ }^{55}$ short side chain perfluorosulfonic acid membranes, ${ }^{56}$ and so on. However, more work needs to be done to make these membranes more robust. For example, the mechanical stabilities of mixed matrix membranes could be a problem due to the addition of particles.

\subsection{Keywords analysis}

As revealed by Table 7, Fuel cell was obviously the keyword with highest frequency. This result agreed well with the above discussions. In brief, the development of ion exchange membranes was mainly driven by two worldwide issues/ concerns, i.e. energy and water. Fuel cell was on the energy side. Besides, Fuel cell and Proton exchange membrane had the highest cooccurrence frequency, followed by Fuel cell and

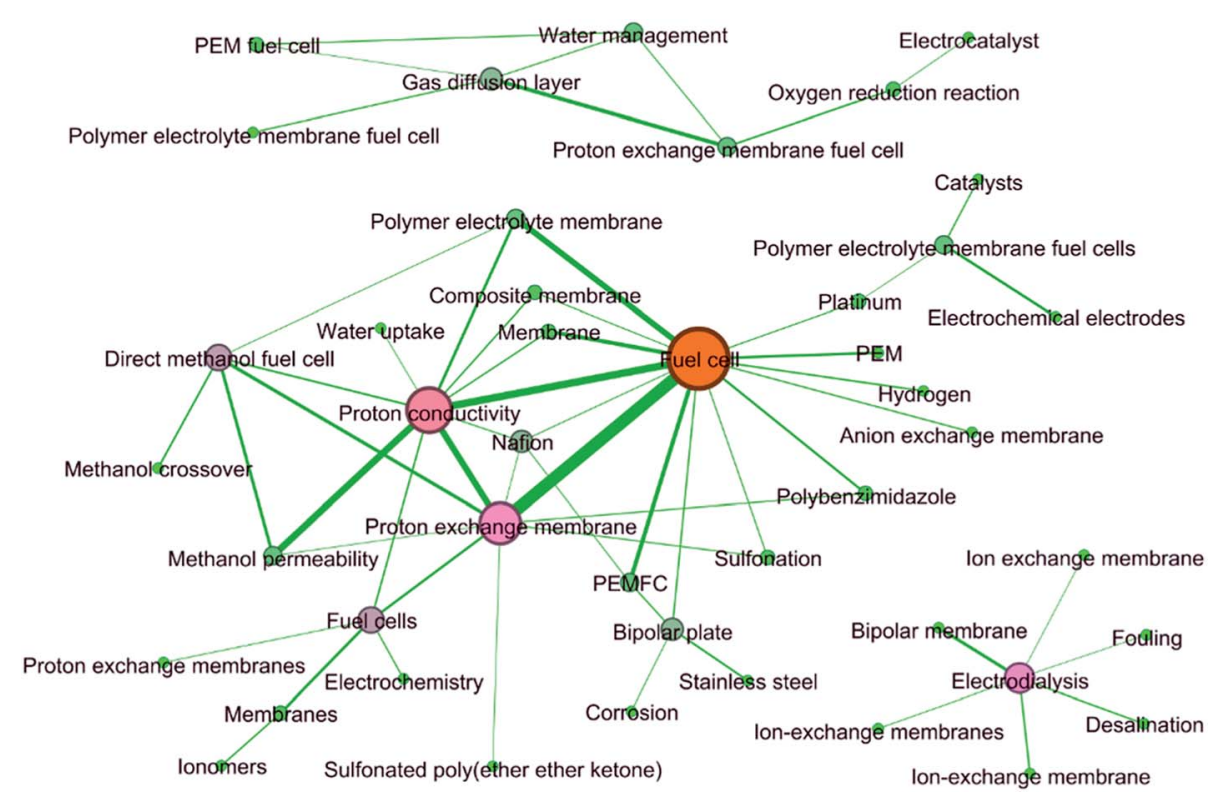

Fig. 11 Keywords network graph. Keywords whose cooccurrence exceeded 30 times were connected with lines. 


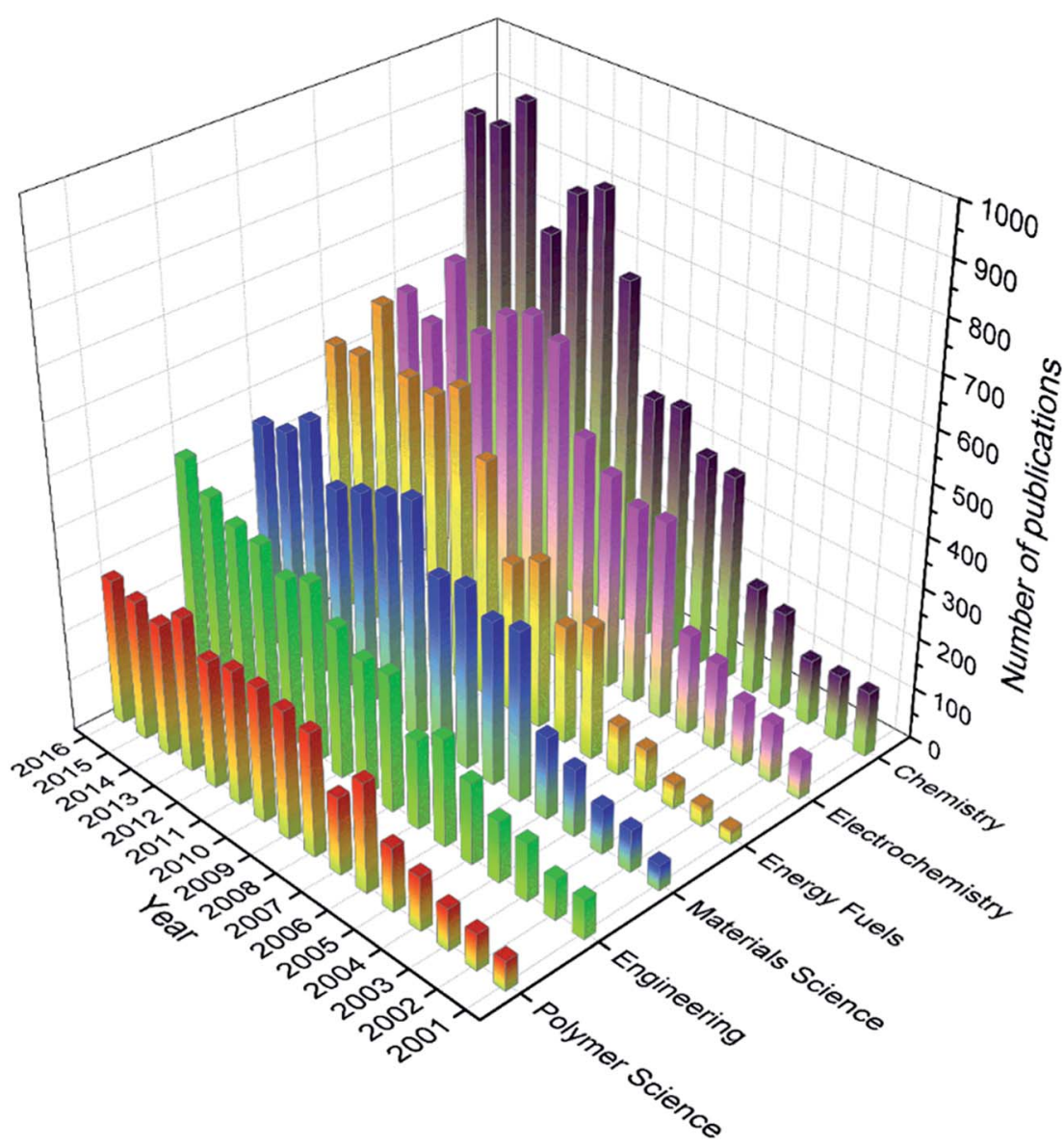

Fig. 12 Number of publications in the top six research areas every year from 2001 to 2016.

Proton conductivity. Interestingly, as shown in Fig. 11, there were three independent keywords networks. The Fuel cellcentered network and the Electrodialysis-centered network revealed the two most studied applications of ion exchange membranes. This result was consistent with the analysis from the previous sections.

\subsection{Research areas analysis}

The research areas discussed in this section referred to the categories in the SC attribute in the database where SC was short for research areas as defined by Web of Science. The 18166 articles were categorized into 68 research areas, and these research areas appeared 37873 times in total, meaning that one article were categorized into two research areas on average. Specifically, 18 of the 68 research areas had 100 articles or more, and only 8 out of the 68 research areas had 1000 articles or more (see Fig. S2 in the ESI $\dagger$ ). Interestingly, there seemed to be a big gap between the $8^{\text {th }}$ research area and the $9^{\text {th }}$ research area, where the former had more than 1000 articles while the latter had less than 500 articles. Moreover, from $1^{\text {st }}$ to $8^{\text {th }}$, the number of publications decreased very quickly compared to that from $8^{\text {th }}$ to the last one. The most common research area was Chemistry, and 8227 articles were categorized into this area. In other words, $45.3 \%$ of the total articles were categorized into Chemistry. The next top five research areas were Electrochemistry $\left(36.6 \%, 2^{\text {nd }}\right)$, followed by Energy \& Fuels $\left(29.2 \%, 3^{\text {rd }}\right)$, Materials Science $\left(27.7 \%, 4^{\text {th }}\right)$, Engineering $(22.3 \%$, $\left.5^{\text {th }}\right)$, and Polymer Science $\left(17.6 \%, 6^{\text {th }}\right)$. As revealed by Fig. 12 , almost all of these research areas (except Engineering) seemed to reach a plateau, some of which even showed a tendency to decrease. These trends were generally in line with the overall publication trend discussed in 3.3.

\section{Conclusion}

A comprehensive statistical study on the research of ion exchange membranes was conducted via a scientometric approach. Based on statistical analysis of the 21123 publications which were related to the topic of ion exchange membranes, it was found that article was the dominating type for these publications and accounted for $86.0 \%$ of the total. English was the dominating publishing language for these articles. Specifically, from 2001 to 2016, over 18000 articles were published on ion exchange membranes, indicating researchers' great interest in this topic. Especially, compared to 2001, the number of articles published in 2016 increased approximately six-fold. This trend continued in 2017 since over 2000 articles were published in the year of 2017. Also, these articles were spread across over 1000 different journals, near 100 countries/regions and over 5000 research institutes, 
revealing the importance of ion exchange membrane as well as the broad research interest in this field. Besides, the properties and applications of ion exchange membranes were also discussed statistically. Furthermore, keywords analysis indicated that fuel cell and proton exchange membrane had the highest cooccurrence frequency. Finally, research areas analysis revealed that ion exchange membranes had a close relation with chemistry, energy and materials. To conclude, this scientometric study provides a statistical analysis on ion exchange membranes and may provide an avenue for future research work in this field.

\section{Data repository}

All raw data used in this study is available from the open access repository: https://doi.org/10.5281/zenodo.1227129.

\section{Conflicts of interest}

The authors declare no conflict of interest.

\section{Acknowledgements}

B. P. Ladewig gratefully acknowledges financial support from Imperial College London (ICL). S. Jiang gratefully acknowledges financial support from the Dept. of Chemical Engineering at ICL. K. F. L. Hagesteijn gratefully acknowledges financial support from the Dept. of Chemical Engineering at ICL and Statoil. J. Ni gratefully acknowledges the China Scholarship Council for financial support.

\section{References}

1 T. Jahnke, G. Futter, A. Latz, T. Malkow, G. Papakonstantinou, G. Tsotridis, P. Schott, M. Gérard, M. Quinaud, M. Quiroga, A. A. Franco, K. Malek, F. CalleVallejo, R. Ferreira De Morais, T. Kerber, P. Sautet, D. Loffreda, S. Strahl, M. Serra, P. Polverino, C. Pianese, M. Mayur, W. G. Bessler and C. Kompis, Performance and degradation of proton exchange membrane fuel cells: state of the art in modeling from atomistic to system scale, $J$. Power Sources, 2016, 304, 207-233, DOI: 10.1016/ j.jpowsour.2015.11.041.

2 C. Santoro, C. Arbizzani, B. Erable and I. Ieropoulos, Microbial fuel cells: From fundamentals to applications. A review, J. Power Sources, 2017, 356, 225-244, DOI: 10.1016/ j.jpowsour.2017.03.109.

3 A. Luiz, E. Spencer, D. D. McClure, H. G. L. Coster, G. W. Barton and J. M. Kavanagh, Membrane selection for the desalination of bio-refinery effluents using electrodialysis, Desalination, 2018, 428, 1-11, DOI: 10.1016/ j.desal.2017.11.006.

4 S. Bunani, N. Kabay, S. Bunani, M. Arda, K. Yoshizuka, S. Nishihama and S. Bunani, Effect of process conditions on recovery of lithium and boron from water using bipolar membrane electrodialysis (BMED), Desalination, 2017, 416, 10-15, DOI: 10.1016/j.desal.2017.04.017.
5 E. Farrell, M. I. Hassan, R. A. Tufa, A. Tuomiranta, A. H. Avci, A. Politano, E. Curcio and H. A. Arafat, Reverse electrodialysis powered greenhouse concept for water- and energy-self-sufficient agriculture, Appl. Energy, 2017, 187, 390-409, DOI: 10.1016/j.apenergy.2016.11.069.

6 F. Z. Aouali, M. Becherif, H. S. Ramadan, M. Emziane, A. Khellaf and K. Mohammedi, Analytical modelling and experimental validation of proton exchange membrane electrolyser for hydrogen production, Int. J. Hydrogen Energy, 2017, 42, 1366-1374, DOI: 10.1016/ j.ijhydene.2016.03.101.

7 Y. Li, J. Sniekers, J. C. Malaquias, C. Van Goethem, K. Binnemans, J. Fransaer and I. F. J. Vankelecom, Crosslinked anion exchange membranes prepared from poly(phenylene oxide) (PPO) for non-aqueous redox flow batteries, J. Power Sources, 2018, 378, 338-344, DOI: 10.1016/j.jpowsour.2017.12.049.

8 L. Wang, F. Zhang, Z. Li, J. Liao, Y. Huang, Y. Lei and N. Li, Mixed-charge poly(2,6-dimethyl-phenylene oxide)anion exchange membrane for diffusion dialysis in acid recovery, J. Membr. Sci., 2018, 549, 543-549, DOI: 10.1016/ j.memsci.2017.12.054.

9 Q. Qiu, J. H. Cha, Y. W. Choi, J. H. Choi, J. Shin and Y. S. Lee, Preparation of polyethylene membranes filled with crosslinked sulfonated polystyrene for cation exchange and transport in membrane capacitive deionization process, Desalination, 2017, 417, 87-93, DOI: 10.1016/ j.desal.2017.05.008.

10 L. Alvarado and A. Chen, Electrodeionization: Principles, strategies and applications, Electrochim. Acta, 2014, 132, 583-597, DOI: 10.1016/j.electacta.2014.03.165.

11 S. Jiang and B. P. Ladewig, High Ion-Exchange Capacity Semihomogeneous Cation Exchange Membranes Prepared via a Novel Polymerization and Sulfonation Approach in Porous Polypropylene, ACS Appl. Mater. Interfaces, 2017, 9, 38612-38620, DOI: 10.1021/acsami.7b13076.

12 J. Ran, L. Wu, Y. He, Z. Yang, Y. Wang, C. Jiang, L. Ge, E. Bakangura and T. Xu, Ion exchange membranes: new developments and applications, J. Membr. Sci., 2017, 522, 267-291, DOI: 10.1016/j.memsci.2016.09.033.

13 K. F. L. Hagesteijn, S. Jiang and B. P. Ladewig, A review of the synthesis and characterization of anion exchange membranes, J. Mater. Sci., 2018, 53, 11131-11150, DOI: 10.1007/s10853-018-2409-y.

14 M. Herrero-Gonzalez, P. Diaz-Guridi, A. Dominguez-Ramos, R. Ibañez and A. Irabien, Photovoltaic solar electrodialysis with bipolar membranes, Desalination, 2018, 433, 155-163, DOI: 10.1016/j.desal.2018.01.015.

15 A. M. Ashrafi, N. Gupta and D. Neděla, An investigation through the validation of the electrochemical methods used for bipolar membranes characterization, J. Membr. Sci., 2017, 544, 195-207, DOI: 10.1016/j.memsci.2017.09.026.

16 A. Ozden, S. Shahgaldi, J. Zhao, X. Li and F. Hamdullahpur, Assessment of graphene as an alternative microporous layer material for proton exchange membrane fuel cells, Fuel, 2018, 215, 726-734, DOI: 10.1016/j.fuel.2017.11.109. 
17 R. Long, B. Li, Z. Liu and W. Liu, A hybrid system using a regenerative electrochemical cycle to harvest waste heat from the proton exchange membrane fuel cell, Energy, 2015, 93, 2079-2086, DOI: 10.1016/j.energy.2015.09.132.

18 W. Zhang, M. Miao, J. Pan, A. Sotto, J. Shen, C. Gao and B. Van der Bruggen, Separation of divalent ions from seawater concentrate to enhance the purity of coarse salt by electrodialysis with monovalent-selective membranes, Desalination, 2017, 411, 28-37, DOI: 10.1016/ j.desal.2017.02.008.

19 B. Cohen, N. Lazarovitch and J. Gilron, Upgrading groundwater for irrigation using monovalent selective electrodialysis, Desalination, 2017, 431, 126-139, DOI: 10.1016/j.desal.2017.10.030.

20 M. Reig, H. Farrokhzad, B. Van der Bruggen, O. Gibert and J. L. Cortina, Synthesis of a monovalent selective cation exchange membrane to concentrate reverse osmosis brines by electrodialysis, Desalination, 2015, 375, 1-9, DOI: 10.1016/j.desal.2015.07.023.

21 E. Güler, W. van Baak, M. Saakes and K. Nijmeijer, Monovalent-ion-selective membranes for reverse electrodialysis, J. Membr. Sci., 2014, 455, 254-270, DOI: 10.1016/j.memsci.2013.12.054.

22 M. Nemati, S. M. Hosseini and M. Shabanian, Novel electrodialysis cation exchange membrane prepared by 2 acrylamido-2-methylpropane sulfonic acid; heavy metal ions removal, J. Hazard. Mater., 2017, 337, 90-104, DOI: 10.1016/j.jhazmat.2017.04.074.

23 Z. Yuan, Q. Dai, L. Qiao, Y. Zhao, H. Zhang and X. Li, Highly stable aromatic poly(ether sulfone) composite ion exchange membrane for vanadium flow battery, J. Membr. Sci., 2017, 541, 465-473, DOI: 10.1016/j.memsci.2017.07.036.

24 M. Irfan, E. Bakangura, N. U. Afsar, M. M. Hossain, J. Ran and $\mathrm{T}$. $\mathrm{Xu}$, Preparation and performance evaluation of novel alkaline stable anion exchange membranes, J. Power Sources, 2017, 355, 171-180, DOI: 10.1016/ j.jpowsour.2017.03.146.

25 J. Mingers and L. Leydesdorff, A review of theory and practice in scientometrics, Eur. J. Oper. Res., 2015, 246, 1-19, DOI: 10.1016/j.ejor.2015.04.002.

26 T. O. Olawumi and D. W. M. Chan, A scientometric review of global research on sustainability and sustainable development, J. Cleaner Prod., 2018, 183, 231-250, DOI: 10.1016/j.jclepro.2018.02.162.

27 Q. He, G. Wang, L. Luo, Q. Shi, J. Xie and X. Meng, Mapping the managerial areas of Building Information Modeling (BIM) using scientometric analysis, Int. J. Proj. Manag., 2017, 35, 670-685, DOI: 10.1016/j.ijproman.2016.08.001.

28 C. Brandt, O. Makarewicz, T. Fischer, C. Stein, Y. Pfeifer, G. Werner and M. W. Pletz, The bigger picture: The history of antibiotics and antimicrobial resistance displayed by scientometric data, Int. J. Antimicrob. Agents, 2014, 44, 424430, DOI: 10.1016/j.ijantimicag.2014.08.001.

29 V. R. Stamenkovic, B. Fowler, B. S. Mun, G. Wang, P. N. Ross, C. A. Lucas and N. M. Markovic, Improved Oxygen Reduction Activity on Pt3Ni(111) via Increased Surface Site Availability, Science, 2007, 315, 493-497, DOI: 10.1126/science.1135941.
30 B. Lim, M. Jiang, P. H. C. Camargo, E. C. Cho, J. Tao, X. Lu, Y. Zhu and Y. Xia, Pd-Pt bimetallic nanodendrites with high activity for oxygen reduction, Science, 2009, 324, 1302-1305, DOI: 10.1126/science.1170377.

31 M. Lefèvre, E. Proietti, F. Jaouen and J. P. Dodelet, IronBased catalysts with improved oxygen reduction activity in polymer electrolyte fuel cells, Science, 2009, 324, 71-74, DOI: $10.1126 /$ science.1170051.

32 J. Greeley, I. E. L. Stephens, A. S. Bondarenko, T. P. Johansson, H. A. Hansen, T. F. Jaramillo, J. Rossmeisl, I. Chorkendorff and J. K. Nørskov, Alloys of platinum and early transition metals as oxygen reduction electrocatalysts, Nat. Chem., 2009, 1, 552-556, DOI: 10.1038/nchem.367.

33 G. Nagel, T. Szellas, W. Huhn, S. Kateriya, N. Adeishvili, P. Berthold, D. Ollig, P. Hegemann and E. Bamberg, Channelrhodopsin-2, a directly light-gated cation-selective membrane channel, Proc. Natl. Acad. Sci. U. S. A., 2003, 100, 13940-13945, DOI: 10.1073/pnas.1936192100.

$34 \mathrm{H}$. Liu and B. E. Logan, Electricity generation using an aircathode single chamber microbial fuel cell in the presence and absence of a proton exchange membrane, Environ. Sci. Technol., 2004, 38, 4040-4046, DOI: 10.1021/es0499344.

35 F. Wang, M. Hickner, Y. S. Kim, T. A. Zawodzinski and J. E. McGrath, Direct polymerization of sulfonated poly(arylene ether sulfone) random (statistical) copolymers: Candidates for new proton exchange membranes, $J$. Membr. Sci., 2002, 197, 231-242, DOI: 10.1016/S03767388(01)00620-2.

36 E. J. Popczun, J. R. McKone, C. G. Read, A. J. Biacchi, A. M. Wiltrout, N. S. Lewis and R. E. Schaak, Nanostructured nickel phosphide as an electrocatalyst for the hydrogen evolution reaction, J. Am. Chem. Soc., 2013, 135, 9267-9270, DOI: 10.1021/ja403440e.

37 D. B. Levin, L. Pitt and M. Love, Biohydrogen production: Prospects and limitations to practical application, Int. J. Hydrogen Energy, 2004, 29, 173-185, DOI: 10.1016/S03603199(03)00094-6.

38 P. J. Ferreira, G. J. la O', Y. Shao-Horn, D. Morgan, R. Makharia, S. Kocha and H. A. Gasteiger, Instability of $\mathrm{Pt} / \mathrm{C}$ Electrocatalysts in Proton Exchange Membrane Fuel Cells, J. Electrochem. Soc., 2005, 152, A2256, DOI: 10.1149/ 1.2050347.

39 K. Schmidt-Rohr and Q. Chen, Parallel cylindrical water nanochannels in Nafion fuel-cell membranes, Nat. Mater., 2008, 7, 75-83, DOI: 10.1038/nmat2074.

40 C. G. Van de Walle and J. Neugebauer, Universal alignment of hydrogen levels in semiconductors, insulators and solutions, Nature, 2003, 423, 626-628, DOI: 10.1038/ nature 01665 .

41 J. H. Nam and M. Kaviany, Effective diffusivity and watersaturation distribution in single- and two-layer PEMFC diffusion medium, Int. J. Heat Mass Transfer, 2003, 46, 4595-4611, DOI: 10.1016/S0017-9310(03)00305-3.

42 C. Wang, M. Waje, X. Wang, J. M. Tang, R. C. Haddon and Y. Yan, Proton Exchange Membrane Fuel Cells with 
Carbon Nanotube Based Electrodes, Nano Lett., 2004, 4, 345348, DOI: 10.1021/nl034952p.

43 P. Xing, G. P. Robertson, M. D. Guiver, S. D. Mikhailenko, K. Wang and S. Kaliaguine, Synthesis and characterization of sulfonated poly(ether ether ketone) for proton exchange membranes, J. Membr. Sci., 2004, 229, 95-106, DOI: 10.1016/j.memsci.2003.09.019.

44 Z. H. Wang, C. Y. Wang and K. S. Chen, Two-phase flow and transport in the air cathode of proton exchange membrane fuel cells, J. Power Sources, 2001, 94, 40-50, DOI: 10.1016/ S0378-7753(00)00662-5.

45 B. Logan, S. Cheng, V. Watson and G. Estadt, Graphite fiber brush anodes for increased power production in air-cathode microbial fuel cells, Environ. Sci. Technol., 2007, 41, 33413346, DOI: 10.1021/es062644y.

46 S. Cheng, H. Liu and B. E. Logan, Increased performance of single-chamber microbial fuel cells using an improved cathode structure, Electrochem. Commun., 2006, 8, 489-494, DOI: 10.1016/j.elecom.2006.01.010.

47 S. M. Haile, D. A. Boysen, C. R. I. Chisholm and R. B. Merie, Solid acids as fuel cell electrolytes, Nature, 2001, 410, 910913, DOI: 10.1038/35073536.

48 C. Rice, S. Ha, R. I. Masel, P. Waszczuk, A. Wieckowski and T. Barnard, Direct formic acid fuel cells, J. Power Sources, 2002, 111, 83-89, DOI: 10.1016/S0378-7753(02)00271-9.

49 F. A. Zakil, S. K. Kamarudin and S. Basri, Modified Nafion membranes for direct alcohol fuel cells: an overview, Renewable Sustainable Energy Rev., 2016, 65, 841-852, DOI: 10.1016/j.rser.2016.07.040.
50 A. Kraytsberg and Y. Ein-Eli, Review of advanced materials for proton exchange membrane fuel cells, Energy Fuels, 2014, 28, 7303-7330, DOI: 10.1021/ef501977k.

51 S. Chabi, A. G. Wright, S. Holdcroft and M. S. Freund, Transparent Bipolar Membrane for Water Splitting Applications, ACS Appl. Mater. Interfaces, 2017, 9, 2674926755, DOI: 10.1021/acsami.7b04402.

52 J. Pan, L. Hou, Q. Wang, Y. He, L. Wu, A. N. Mondal and T. $\mathrm{Xu}$, Preparation of bipolar membranes by electrospinning, Mater. Chem. Phys., 2017, 186, 484-491, DOI: 10.1016/j.matchemphys.2016.11.023.

53 O. Schmidt, A. Gambhir, I. Staffell, A. Hawkes, J. Nelson and S. Few, Future cost and performance of water electrolysis: an expert elicitation study, Int. J. Hydrogen Energy, 2017, 42, 30470-30492, DOI: 10.1016/j.ijhydene.2017.10.045.

54 M. Schalenbach, M. Carmo and D. L. Fritz, Pressurized PEM water electrolysis: efficiency and gas crossover, Int. J. Hydrogen Energy, 2013, 38, 14921-14933, DOI: 10.1016/ j.ijhydene.2013.09.013.

55 S. M. Hosseini, M. Nemati, F. Jeddi, E. Salehi, A. R. Khodabakhshi and S. S. Madaeni, Fabrication of mixed matrix heterogeneous cation exchange membrane modified by titanium dioxide nanoparticles: mono/bivalent ionic transport property in desalination, Desalination, 2015, 359, 167-175, DOI: 10.1016/j.desal.2014.12.043.

$56 \mathrm{X}$. Luo and S. Holdcroft, Water transport through short side chain perfluorosulfonic acid ionomer membranes, J. Membr. Sci., 2016, 520, 155-165, DOI: 10.1016/j.memsci.2016.07.021. 